\title{
Potential Cultivation of Halophilic Oleaginous Microalgae on Industrial Wastewater
}

\author{
Dorya Essa ${ }^{(1)}$, Atef M. Abo-Shady ${ }^{(1)}$, Hanan M. Khairy ${ }^{(2)}$, Abd El-Fatah \\ Abomohra $^{(1,3)}$ and Mostafa E. Elshobary ${ }^{(1) \#}$ \\ (1) Botany Department, Faculty of Science, Tanta University, Tanta and (2) National \\ Institute of Oceanography \& Fisheries, Alexandria, Egypt and ${ }^{(3)}$ Botany Department, \\ School of Energy and Power Engineering, Jiangsu University, 212013 Jiangsu, China.
}

\begin{abstract}
$\mathbf{M}$ ICROALGAE cultivation offers an effective solution for wastewater treatment, as they provide a tertiary bio-treatment coupled with the production of valuable biomass, which can be further used for different purposes. Using wastewater for microalgal cultivation is beneficial for minimizing the use of water, reducing the cost of nutrient addition and removing nitrogen and phosphorus from wastewater.

Lipids obtained from marine Nannochloropsis oculata and Tetraselmis chuii microalgae have received growing attention for the production of biofuels. In the present study, the effluent of El-Malyaa Company (EMC) and Salt and Soda Company (ESC) were used as growth media for the two tested oleaginous marine microalgae. Wastewater was used in different ratios with sterilized seawater, or mixed with synthetic medium (F/2). The growth was evaluated by optical density and dry weight, total lipids content and productivity were also determined.

The results showed that the tested species were capable of growing on the effluent wastewater of the two companies. In addition, dilution of the industrial wastewater with seawater or its mixing with synthetic culture medium $(\mathrm{F} / 2)$ increased growth of the two tested marine microalgae. The maximum growth was recorded using a ratio of 25:75 of F/2 medium: the effluent of both companies. However, the highest lipid content and lipid productivity were recorded using a ratio of 75:25 of F/2 medium: the effluent of both companies. Therefore, this study suggests that it is possible to utilize a mixture of industrial wastewater and synthetic medium for potential biomass and lipid production from microalgae for biofuel production.
\end{abstract}

Keywords: Biomass, Lipid, Marine, Microalgae, Oleaginous, Wastewater.

\section{Introduction}

Rapid industrialization, population growth, and complete ignoring for environmental health have led to serious environmental pollution (Dash et al., 2013). Among all the environmental pollutions, Water pollution is a critical growing problem (Karuppaiah et al., 2015). Pollution is a man-made phenomenon, arising either when the concentrations of naturally occurring substances are increased or when synthetic compounds are released into the environment (Abdel-Raouf et al., 2012). Releasing of organic and inorganic substances into the environment as a result of industrial, agricultural and domestic water activities causing many organic and inorganic pollution (Mouchet 1986 and Lim et al., 2010). Wastewater is essentially the end product generated by industrial, municipal, agricultural, and domestic sources (Ellis, 2011). These waste water resources can be used as an alternative to the use of synthetic fertilizers, which are rich in organic and inorganic pollutants such as nitrogen and phosphorus (Sutherland et al., 2014),

Simultaneously, with the cultivation of microalgae using wastes and wastewaters for biomass production these pollutants could be removed from the aquatic environment. Compared to physical and chemical water treatment processes, algae biotreatment can potentially achieve organic wastes removal in a less expensive and enviromentally safer way with the added benefits of resource recovery and recycling (Oswald, 2003). Microalgae assimilate a potenial amount of nutrients because they require 
high amounts of phosphorus and nitrogen for the synthesis of $45-60 \%$ proteins of microalgal dry weight, nucleic acids and phospholipids. Nutrient removal can also be increased by $\mathrm{NH}_{3}$ removing or phosphorus precipitation due to the increasing of the $\mathrm{pH}$ associated with photosynthesis (Oswald, 1988).

Recent researches indicated significance mass production of algal biomass for biofuel and other applications using wastewaters and lipids obtained from microalgae have received more attention during the last decade for the production of biofuels (Zhou, 2011). Biofuels are considered to be one of the potenial alternative energy sources, as they are renewable, and environment-friendly. Microalgae were discussed to be the promising source for biodiesel due to their simplicity structure, higher growth rate and higher lipid content than terrestrial plants, moreover, most of microalgae can complete an entire growing cycle every few days, which results in higher oil productivity than other oil crops (Stephens et al., 2010). The yield of oil from algae is over 200 times the yield of soybean oils (Gouveia \& Oliverira, 2009). Furthermore, microalgae can also be grown on non-arable lands (e.g. desert, seashore, rocky and sandy lands) which do not compete with food crops and can use saline water instead of fresh water of irrigation and drinking. Microalgae are able to produce various forms of biofuels including microalgal lipidderived biodiesel (Scott et al., 2010), bioethanol by fermentation of carbohydrate (Dismukes et al., 2008), and biohydrogen from photosynthesis or fermentation (Hemschemeier et al., 2009).

In earlier 2000s, there were less or no researches were carried out in such a way which integrates the treatment of industrial wastewater with biomass productivity (Umamaheswari \& Shanthakumar, 2016). In Egypt, Many factories drain there industrial wastes in the river and the canal causing serious environmental problems, affecting negatively the stability of many aquatic ecosystems and can also cause adverse effects to human health and the environment directly or indirectly. In our study we focused on two companies, Salt and Soda and Elmalyaa in Kafr El-zayat that drain their wastes directly to the Ganag drain for mass production and lipid content of two marine microalgal species.

\section{Materials and Methods}

\section{Culture media}

The F/2 medium contained (mg. $\mathrm{L}^{-1}$ ) $\mathrm{NaNO}_{3}, \quad 75 ; \quad \mathrm{NaH}_{2} \mathrm{PO} 4 . \mathrm{H}_{2} 0, \quad 5 ; \mathrm{Na}_{2}$ EDTA. $\mathrm{H}_{2} 0,4.16 ; \mathrm{FeCl}_{3} .6 \mathrm{H}_{2} 0,3.15 ; \mathrm{CuSO}_{4} \cdot 5 \mathrm{H}_{2} 0$, $0.01 ; \mathrm{ZnSO}_{4} .7 \mathrm{H}_{2} 0,0.022 ; \mathrm{CoCl}_{2} .6 \mathrm{H}_{2} 0,0.01$; $\mathrm{MnCl}_{2} .4 \mathrm{H}_{2} 0, \quad 0.18 ; \quad \mathrm{Na}_{2} \mathrm{MoO} 4.2 \mathrm{H}_{2} 0, \quad 0.006$; Vitamin $\mathrm{B}_{12}, 0.0005$; Vitamin $\mathrm{B}_{1}, 0.1$; and Bi-tin, 0.0005 (Guillard \& Ryther, 1962). The seawater used in the study was obtained from Alexandria Beach (Egypt). The wastewater used as a nutrient source was collected from Ganag drain in Kafr El-zayat City El-Gharbya Governorate, Egypt, that receives the effluent of Salt and Soda (ESC), which produce oil, soap and fodder and El-malyaa Company (EMC) which produce chemicals.

\section{Physico-chemical characteristics of water samples}

The initial physico-chemical analysis of wastewater samples was made before inoculation of tested microalgal species. Total dissolved solids (T.D.S) were measured using YSI Model 33 (yellow springs) S-C-T meter, $\mathrm{pH}$ : using a pocket $\mathrm{pH}$ meter (Research model 201/ Digital pH meter), Nitrate-nitrogen according to (Strickland \& Parsons, 1965), Ammonia-nitrogen according to Jackson (1960) and Allen et al. (1974) and Phosphate according to Strickland \& Parsons (1972)

\section{Tested microalgal species}

The species selected for cultivation were a strain of Tetraselmis chuii and Nannochloropsis oculata were kindly provided from Invertebrate Lab., National Institute of Oceanography and Fisheries, Alexandria, Egypt. The microalgal species were chosen due to their high lipids contentaccording to literature screening.

\section{Cultivation conditions}

The overall ability of the two tested species to use the effluent of industrial wastewater of the two companies as a nutrient source was evaluated, then evaluating the growth of tested species on the diluted industrial wastewater with sterilized and filtered seawateror on mixed wastewater with synthetic F/2 (Guillard \& Ryther, 1962) enriched medium with four different concentrations: $(25 \%, 50 \%, 75 \%$ and $100 \%)$. Certain volume of exponentially growing pre cultured microalgae strains were inoculated to $650 \mathrm{ml}$ of each specific sterilized culture medium (F/2 enriched seawater medium) in 1L Erlenmeyer flasks used as a control. The same volume of exponentially 
growing pre cultured microalgae strains were inoculated to $650 \mathrm{ml}$ of the mixture of wastewater (EMC and ESC) and sterilized and filtered seawater or with synthetic medium $\mathrm{F} / 2$ in $1 \mathrm{~L}$ Erlenmeyer flasks $(25 \%, 50 \%, 75 \%$ and $100 \%)$. Aeration was provided to culture through silicon pipes whose one end is inserted into the culture flask and other end to the aerator which helped to provide aeration for proper mixing of cells in the culture flasks. Algal culture flasks were then incubated under continuous fluorescent light of $80 \mu \mathrm{mol} \mathrm{m}-2 \mathrm{~s}^{-1}$ and temperature at $26^{\circ} \mathrm{C} \pm 1^{\circ} \mathrm{C}$.

\section{Growth assay}

Growth curves were evaluated by measuring the optical density at 680nm using spectrophotometer (SHIMADZU UV- 2401PC, Japan) and algal dry weight (g.L $\left.\mathrm{L}^{-1}\right)$. Dry weight was estimated by centrifugation of $40 \mathrm{ml}$ of the culture at 2000 round for $10 \mathrm{~min}$, and then cell pellets were washed twice using distilled water, and then dried in the oven at $80^{\circ} \mathrm{C}$ until constant weight. The biomass productivity BP $\left(\right.$ g. $\left.\mathrm{L}^{-1} \mathrm{~d}^{-1}\right)$ was calculated by equation: $\mathrm{BP}=(\mathrm{WBF}-\mathrm{WB} 0) / \mathrm{t}$, where WB0 and WBF are the weights of dry biomass at the beginning and the end of a batch run and $t$ is the overall culture time.

\section{Estimation of total lipids}

Extraction of lipids was done using chloroform: methanol (2:1) according to the method described by Folch et al. (1957). The pre-weighted glass vials containing the lipid extracts were dried at $80^{\circ} \mathrm{C}$ for $30 \mathrm{~min}$, cooled in a desiccator and weighed. Lipids productivity PL was calculated by the equation: $\mathrm{PL}=(\mathrm{WLF}-\mathrm{WL} 0) / \mathrm{t}$, where WLO and WLF are the weights of lipids content at the beginning and the end of a batch run and " $\mathrm{t}$ " is the overall culture time.

\section{Statistical analysis}

Results are presented as mean \pm standard deviation of the mean, $n=3$. The statistical analyses were carried out using the SPSS program, SPSS 10.0 Software (SPSS, Richmond, VA, USA) as described by Dytham (1999). Data were analyzed to determine the degree of significance between treatments using one way analysis of variance (ANOVA) with Duncan's multiple range tests for comparison of the significance level between values at $\mathrm{P}<0.05$ level of significance.

\section{Results and Discussion}

\section{Wastewater analysis}

The wastewater used in the experiments that was collected from Ganagdrain was analyzed to estimate its different characters and the results are shown in Table 1. Before cultivation of tested microalgal species we sterilized the effluent of the two companies in order to kill any microbial contaminants as well as any pathogen. The chemical composition including essential nutrients of wastewater may be even changed under the effect of sterilization due to high pressure and temperature. Where, the stability of compounds and the affinity between different elements decreased, so more nutrients will be released such as $\mathrm{NO}_{3}$ and $\mathrm{NH}_{3}$ and others will be decomposed such as organic matter while the values of TDS and $\mathrm{PO}_{4}$ decreased due to precipitation. So, the values of TDS and $\mathrm{PO}_{4}$ decreased but values of $\mathrm{pH}, \mathrm{NO}_{3}$ and $\mathrm{NH}_{4}$ increased and these results were in agreement with the results obtained by El-Sheekh et al. (2005) and Stover et al. (1976) who mentioned that the nutrients and metals are presented in complex organic form in sludge and are rather stable under normal conditions due to retention mechanisms including ion exchange, sorption, chelating and precipitation.

TABLE 1. Characterization of the wastewater of El- Malyaa Company (EMC) and Salt and Soda Company (ESC) before and after sterilization.

\begin{tabular}{|c|c|c|c|c|c|c|c|c|c|c|}
\hline \multirow{2}{*}{$\begin{array}{l}\text { Water } \\
\text { sample }\end{array}$} & \multicolumn{2}{|c|}{ pH } & \multicolumn{2}{|c|}{ TDS mg.L $\mathbf{L}^{-1}$} & \multicolumn{2}{|c|}{$\mathrm{PO}_{4} \mathrm{mg} \cdot \mathrm{L}^{-1}$} & \multicolumn{2}{|c|}{$\mathrm{NO}_{3} \mathrm{mg} \cdot \mathrm{L}^{-1}$} & \multicolumn{2}{|c|}{$\mathrm{NH}_{3} \mathrm{mg} \cdot \mathrm{L}^{-1}$} \\
\hline & ESC & EMC & ESC & EMC & ESC & EMC & ESC & EMC & ESC & EMC \\
\hline $\begin{array}{l}\text { Raw } \\
\text { waste water }\end{array}$ & $\begin{array}{c}6.5 \pm \\
0.025\end{array}$ & $\begin{array}{l}7.12 \pm \\
0.033\end{array}$ & $\begin{array}{c}827 \pm \\
2\end{array}$ & $\begin{array}{c}734 \pm \\
1.5\end{array}$ & $\begin{array}{l}5.06 \pm \\
0.034\end{array}$ & $\begin{array}{c}10.05 \pm \\
0.045\end{array}$ & $\begin{array}{l}3.87 \pm \\
0.005\end{array}$ & $\begin{array}{l}4.95 \pm \\
0.045\end{array}$ & $\begin{array}{c}0.105 \pm \\
0.001\end{array}$ & $\begin{array}{l}0.09 \pm \\
0.001\end{array}$ \\
\hline $\begin{array}{l}\text { Waste water } \\
\text { after } \\
\text { sterilization } \\
\text { (control) }\end{array}$ & $\begin{array}{c}7.1 \pm \\
0.027\end{array}$ & $\begin{array}{c}7.6 \pm \\
0.031\end{array}$ & $\begin{array}{c}683 \pm \\
2.4\end{array}$ & $\begin{array}{c}543 \pm \\
1.4\end{array}$ & $\begin{array}{c}4.1 \pm \\
0.033\end{array}$ & $\begin{array}{l}8.65 \pm \\
0.055\end{array}$ & $\begin{array}{c}4.9 \pm \\
0.033\end{array}$ & $\begin{array}{c}5.8 \pm \\
0.045\end{array}$ & $\begin{array}{c}0.142 \pm \\
0.001\end{array}$ & $\begin{array}{c}0.129 \pm \\
0.001\end{array}$ \\
\hline
\end{tabular}


Cultivation of tested microalgal species on a different dilution of treated industrial wastewater (ESC or EMC) and sterilized and filtered seawater

Growth curve

The first test was carried out in order to evaluate whether the selected $N$ oculata and $T$. chuii could be able to utilize nutrients from industrial wastewater. Results showed that both of the tested species could grow using wastewater of the two companies and also dilution increased their growth efficiency. The highest value of optical density was reached at $10^{\text {th }}$ day of incubation on control of F/2 enriched medium that was 0.661 O.D. with T. chuii and 0.563 O.D. with N. oculata while, $75 \%$ EMC showed the highest growth of the diluted samples with 0.302 O.D. in case of $T$. chuii and with 0.252 O.D. with $N$ oculata. $100 \%$ ESC showed the lowest growth values that were (0.088 and 0.155 O.D.) with $N$ oculata and $T$. chuii, respectively as apparent in Fig. 1 and 2.

A
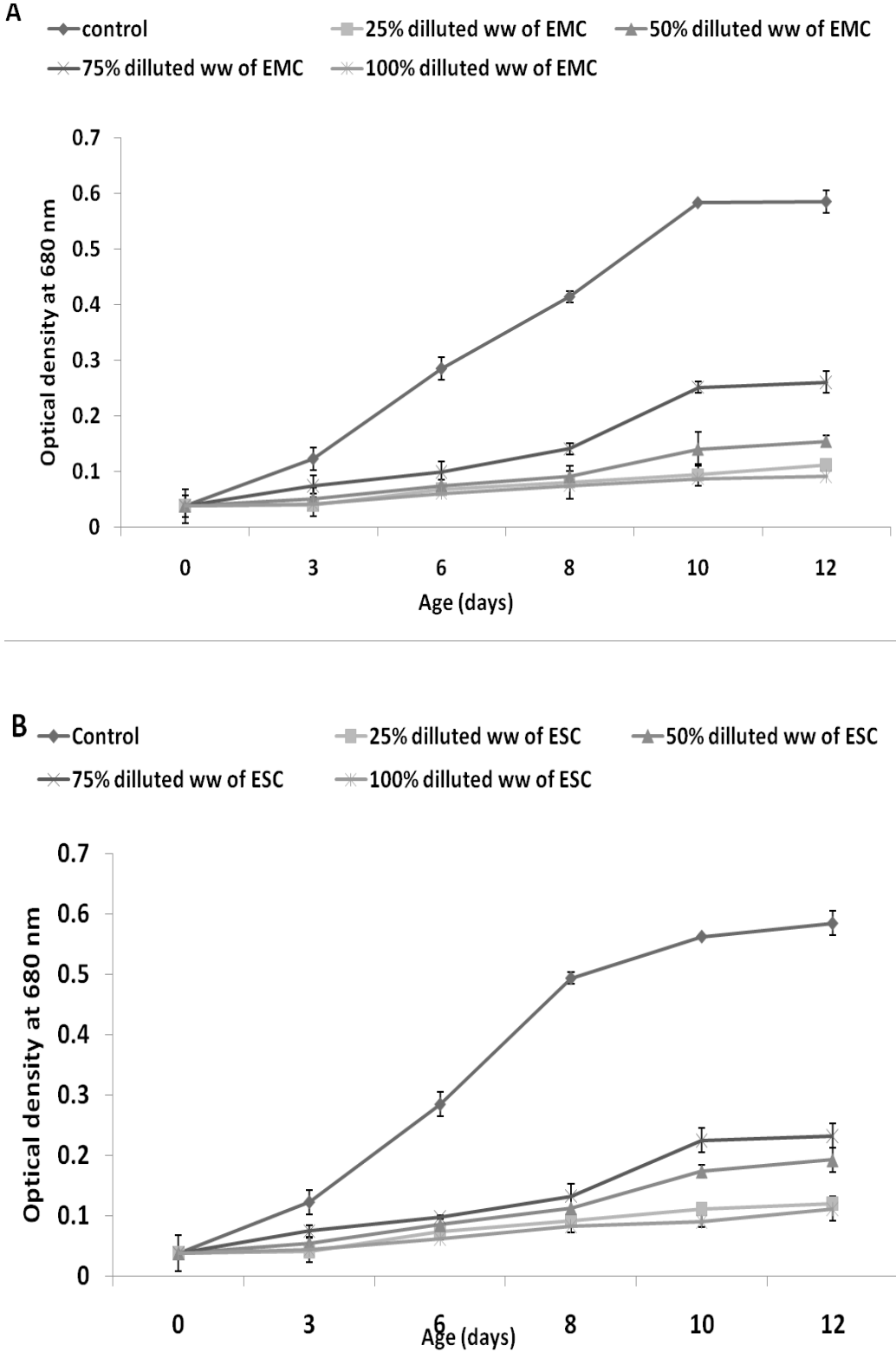

Fig. 1. Growth curves of $N$. oculataon diluted treated industrial wastewater of (A) El- Malyaa Company (EMC), (B) Salt and soda Company (ESC) with seawater measured as optical density at 680nm. Each point represents the mean value of three replicates; bars indicate standard deviations. 


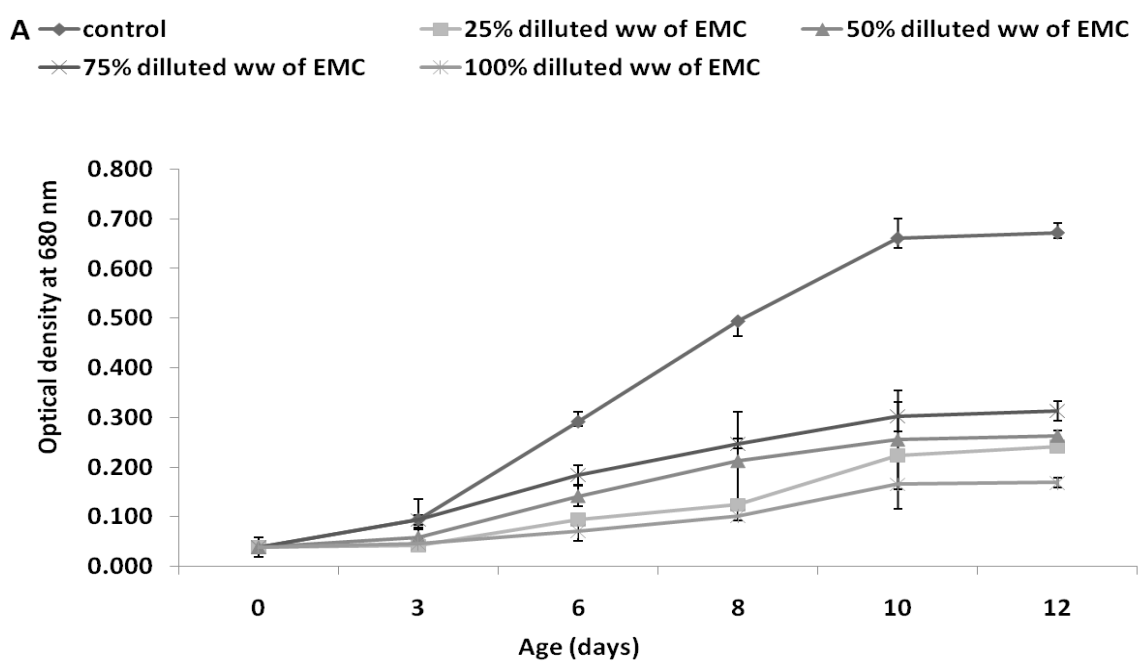

B
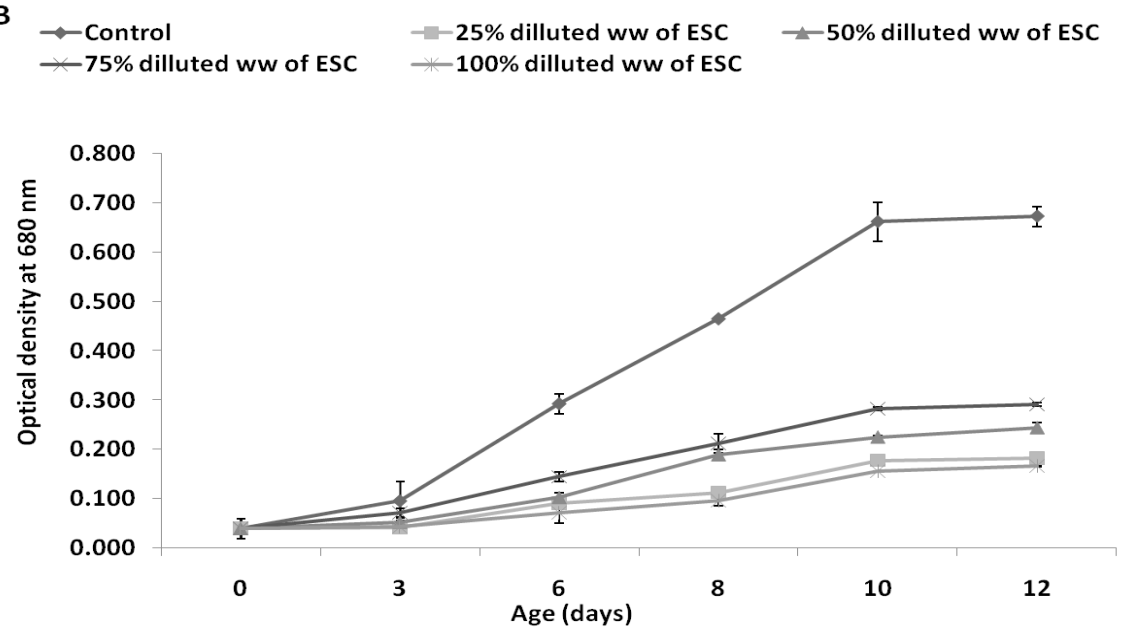

Fig. 2. Growth curves of $T$. chuii on diluted treated industrial wastewater of (A) El- Malyaa Company (EMC), (B) Salt and Soda Company (ESC) with seawater measured as optical density at 680nm. Each point represents the mean value of three replicates; bars indicate standard deviations.

Dry weight and biomass productivity

The amount of dry weight and biomass productivity obtained from each culture medium at the end of the experiment is shown in Table 2. T. chuii showed higher dry weight and biomass productivity than N. oculata and the highest values (the most significant) of dry weight and biomass productivity were observed at cultivation of tested species on $\mathrm{F} / 2$ medium only and these results were in agree with Sousa et al. (2014) who mentioned that the cell density of synthetic medium was higher than the cell concentrations in the experiments with wastewater addition as pure synthetic culture medium provide algae with their all required nutrients showing the best growth rates. Regarding to different dilution concentrations, $75 \% \mathrm{WW}$ concentration showed the highest growth relative to the other dilutions. While $25 \% \mathrm{ESC}$, showed the lowest values $\left(0.22\right.$ g.L. $\mathrm{L}^{-1}$ with $N$. oculata and 0.25 g. $\mathrm{L}^{-1}$ with $T$. chuii) and the slowest growth rates were found in case of using $100 \%$ effluent of wastewater and it was in accordance with Wang et al. (2013) who tried to determine the optimum conditions for Chlorella $\mathrm{sp}$. through diluting the municipal wastewaters in to four different concentrations $(25,50,75$ and $100 \%)$ and found $50 \%$ diluted effluent of wastewater recorded that the highest biomass $\left(0.258\right.$ g. $\left.\mathrm{L}^{-1}\right)$, but like our results they found that the lowest and slowest growth rates were found in $100 \%$ effluent of wastewater due to high concentrations of different constituents of wastewater that strongly reduce microalgal growth. 
TABLE 2. Dry weight and biomass productivity of tested microalgae on diluted industrial wastewater of A, EIMalyaa Company (EMC); B, Salt and Soda Company (ESC) with seawater at the end of exponential phase. Each point represents the mean value of three replicates. Different letters represent significant differences at $\mathbf{P}<0.05$ (Duncans).

\begin{tabular}{|c|c|c|c|c|}
\hline \multirow{2}{*}{$\begin{array}{l}\text { Microalgae } \\
\text { Treatments }\end{array}$} & \multicolumn{2}{|c|}{ N. oculata } & \multicolumn{2}{|r|}{ T. chuii } \\
\hline & $\begin{array}{l}\text { Dry weight } \\
\quad\left(\text { g. } L^{-1}\right)\end{array}$ & $\begin{array}{c}\text { Biomass productivity } \\
\left(\mathrm{g} \cdot \mathrm{L}^{-1} \cdot \mathrm{d}^{-1}\right)\end{array}$ & $\begin{array}{l}\text { Dry weight } \\
\left(\text { g. } \mathrm{L}^{-1}\right)\end{array}$ & $\begin{array}{c}\text { Biomass productivity } \\
\left(\mathrm{g} \cdot \mathrm{L}^{-1} \cdot \mathrm{d}^{-1}\right)\end{array}$ \\
\hline Control & $0.55 \pm 0.01^{\mathrm{A}}$ & $0.054 \pm 0.002^{\mathrm{A}}$ & $0.68 \pm 0.02^{\mathrm{A}}$ & $0.073 \pm 0.003^{\mathrm{A}}$ \\
\hline $25 \% \mathrm{ESC}$ & $0.22 \pm 0.02^{\mathrm{H}}$ & $0.017 \pm 0.001^{\mathrm{BCD}}$ & $0.25 \pm 0.01^{\mathrm{E}}$ & $0.026 \pm 0.004^{\mathrm{D}}$ \\
\hline $50 \%$ ESC & $0.3 \pm 0.03^{\mathrm{D}}$ & $0.026 \pm 0.003^{\mathrm{BC}}$ & $0.32 \pm 0.03^{\mathrm{C}}$ & $0.034 \pm 0.001^{\mathrm{BC}}$ \\
\hline $75 \%$ ESC & $0.39 \pm 0.03^{\text {В }}$ & $0.033 \pm 0.001^{\mathrm{BC}}$ & $0.41 \pm 0.01^{\mathrm{B}}$ & $0.043 \pm 0.001^{\mathrm{B}}$ \\
\hline $100 \% \mathrm{ESC}$ & $0.24 \pm 0.02^{\mathrm{G}}$ & $0.015 \pm 0.002^{\mathrm{CD}}$ & $0.28 \pm 0.02^{\mathrm{D}}$ & $0.027 \pm 0.002^{\mathrm{D}}$ \\
\hline $25 \%$ EMC & $0.25 \pm 0.02^{\mathrm{F}}$ & $0.018 \pm 0.004^{\mathrm{D}}$ & $0.28 \pm 0.02^{\mathrm{D}}$ & $0.028 \pm 0.004^{\mathrm{C}}$ \\
\hline $50 \% \mathrm{EMC}$ & $0.32 \pm 0.01^{\mathrm{C}}$ & $0.026 \pm 0.005^{\mathrm{B}}$ & $0.41 \pm 0.03^{\mathrm{B}}$ & $0.038 \pm 0.005^{\mathrm{B}}$ \\
\hline $75 \%$ EMC & $0.39 \pm 0.01^{\mathrm{B}}$ & $0.034 \pm 0.001^{\mathrm{BC}}$ & $0.30 \pm 0.01^{\mathrm{C}}$ & $0.032 \pm 0.001^{\mathrm{BC}}$ \\
\hline $100 \%$ EMC & $0.29 \pm 0.02^{\mathrm{E}}$ & $0.019 \pm 0.002^{\mathrm{D}}$ & $0.32 \pm 0.02^{\mathrm{C}}$ & $0.032 \pm 0.003^{\mathrm{BC}}$ \\
\hline F value & $506^{* * *}$ & $450 * *$ & $670 * * *$ & $607 * * *$ \\
\hline
\end{tabular}

** Significant at $\mathrm{P} \leq 0.05, * * *$ Significant at $\mathrm{P} \leq 0.005$ and (ns) Non-significant at $\mathrm{P} \leq 0.01$ using one way analysis of variance (ANOVA)

Total lipids content and lipids productivity of tested microalgae

It could be observed that increasing in seawater concentration for dilution of wastewater did not effect on lipids content of tested species and pure wastewater showed the highest lipids content and productivity although it recorded the lowest growth rates and it was in accordance with Karpagam et al. (2015) who found that the stress created that decreased biomass, causing an increasing in lipid content and also Davis et al. (2016) mentioned that, decreased growth rate leads to lipid accumulation. Both of tested microalgal species recorded the highest lipids content and productivity on pure wastewater of El-Malyaa Company that was $0.121 \mathrm{~g} . \mathrm{L}^{-1} \quad 0.012 \mathrm{~g} \cdot \mathrm{L}^{-1} \cdot \mathrm{d}^{-1}$ for $T$. chuii and , 0.114 g. $\mathrm{L}^{-1}, 0.008 \mathrm{~g} . \mathrm{L}^{-1} . \mathrm{d}^{-1}$ for $N$. oculata, respectively. Cultivation of tested species on waste water elevated $\%$ of lipids of dry weight than the control by $20 \%$ and $17 \%$ with $T$. chuii and $17 \%$ and $10 \%$ with $N$. oculata in case of cultivation on ESC and EMC, respectively (Fig. 3).

Cultivation of tested microalgal species on a mixture of different concentrations of treated industrial wastewater (ESC or EMC) and F/2 enriched medium

\section{Growth curve}

It was clearly observed that mixing wastewater with synthetic medium caused significant increase in microalgal growth than its dilution with seawater and it was in agree with Onalo et al. (2014) who mentioned that incase of dilution the available nutrients in diluted wastewater are not sufficient enough for microalgal growth and lower than that available in case of normal artificial media that increase availability of nutrients and supply microalgal cells with different nutrients that are not available in wastewater for enhancing of their growth. $75 \%$ ESC was the best mixture recording the highest OD value that was $(0.455$ and 0.352$)$ in case of $N$. oculata and T. chuii, while $100 \%$ ESC showed the minimum values with tested species as apparent in Fig. 4 and 5.

Dry weight and biomass productivity of tested microalgae

The results indicated that the microalgal growth increased by increasing the concentration of wastewater in the mixture and the highest dry weight and biomass productivity were recorded in case of mixing $75 \%$ of industrial wastewater with $25 \%$ of enriched $\mathrm{F} / 2$ medium regarding other mixtures and the obtained results were relatively close to that of the tested species cultivated on pure synthetic medium only, while cultivation on pure wastewater showed the lowest growth. The obtained results were in accordance with Sousa et al. (2014) who found that increasing wastewater concentration addition $22 \%$ did not obviously increased algal growth, that might be due to the relatively small increase in wastewater concentration. But when they added $44 \%$, cell growth was almost two times higher the addition of 19 and $22 \%$ of the wastewater. T. chuii showed higher dry weight and biomass productivity $(0.611$ g. $\mathrm{L}^{-1}$ and $\left.0.057 \mathrm{~g} . \mathrm{L}^{-1} \cdot \mathrm{d}^{-1}\right)$ than $N$. oculata $(0.587$ g. $\mathrm{L}^{-1}$ and $\left.0.043 \mathrm{~g} . \mathrm{L}^{-1} \cdot \mathrm{d}^{-1}\right)$ on $75 \%$ EMC. It was observed a highly significant effect of the changes of concentrations and companies on dry weight and biomass productivity and there interactionin the two-way ANOVA at $\mathrm{P}<0.05$ (Table 3 ). 
Total lipids content and lipids productivity of tested microalgae

In case of mixing with artificial media, $25 \%$ wastewater: $75 \%$ artificial media (that showed the lowest growth) showed the highest total lipids content that was relatively close to that of $100 \%$ wastewater due to the created stress that decreased biomass, causing an increasing in lipid content. There was a clear significant increase in total lipids content and productivity of $N$. oculata when it was cultivated on $25 \%$ EMC than the control. N. oculataa showed higher lipids content and productivity than

A

口Lipids content
T. chuii $\left(0.185 \mathrm{~g} . \mathrm{L}^{-1}\right.$ and $\left.0.02 \mathrm{~g} \cdot \mathrm{L}^{-1} \cdot \mathrm{d}^{-1}\right)$ in case of $25 \%$ EMC and T. chuii showed its highest lipids content $\left(0.140 \mathrm{~g} . \mathrm{L}^{-1}\right)$ with $25 \%$ ESC and $(0.135 \mathrm{~g}$. $\left.\mathrm{L}^{-1}\right)$ and the highest lipids productivity $\left(0.015 \mathrm{~g} . \mathrm{L}^{-1}\right.$. $\mathrm{d}^{-1}$ ) with $25 \%$ EMC. Mixing of wastewater with synthetic medium caused an obvious increase in the percentage of total lipids of dry weight than the control by $30 \%$ and $20 \%$ with $N$. oculata in case of using 25\% ESC and 25\% EMC, respectively and by $20 \%$ and $8 \%$ with $T$. chuii in case of using $25 \%$ ESC and 25\% EMC, respectively (Fig. 6).
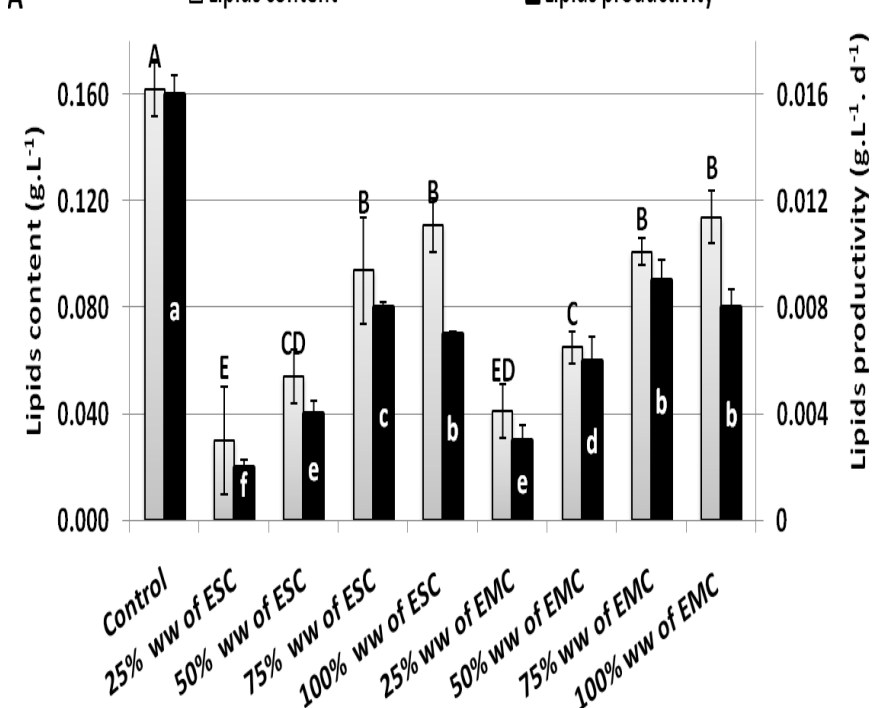

B

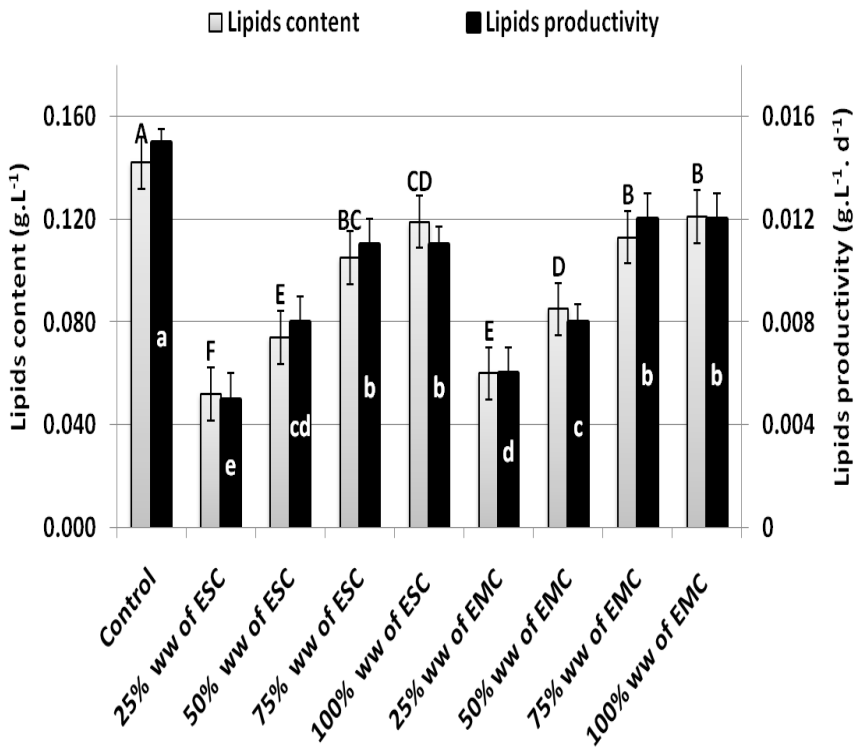

Fig. 3. Total lipids content and lipids productivity of $\mathrm{A}, N$. oculata and $\mathrm{B}, T$. chuii on diluted industrial wastewater (ESC) or (EMC) and seawater during the end of exponential phase. Each point represents the mean value of three replicates; bars indicate standard deviations. Different letters represent significant differences at $\mathbf{P}<0.05$ (Duncans). 
A

$\begin{array}{ll}\rightarrow \text { Control } & -25 \% \text { ww of EMC } \\ -75 \% \text { ww of EMC } & -100 \% \text { ww of EMC }\end{array}$

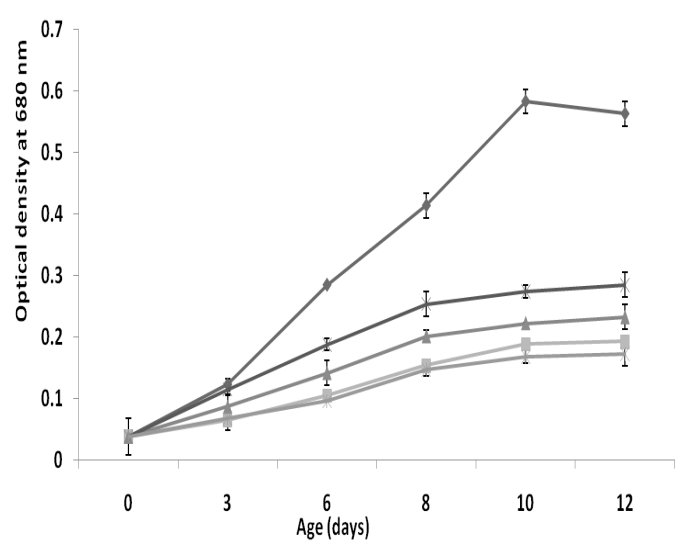

B $\begin{array}{ll}\rightarrow-\text { Control } & -25 \% \text { ww of ESC } \\ \rightarrow-75 \% \text { ww of ESC } & -100 \% \text { ww of ESC }\end{array}$

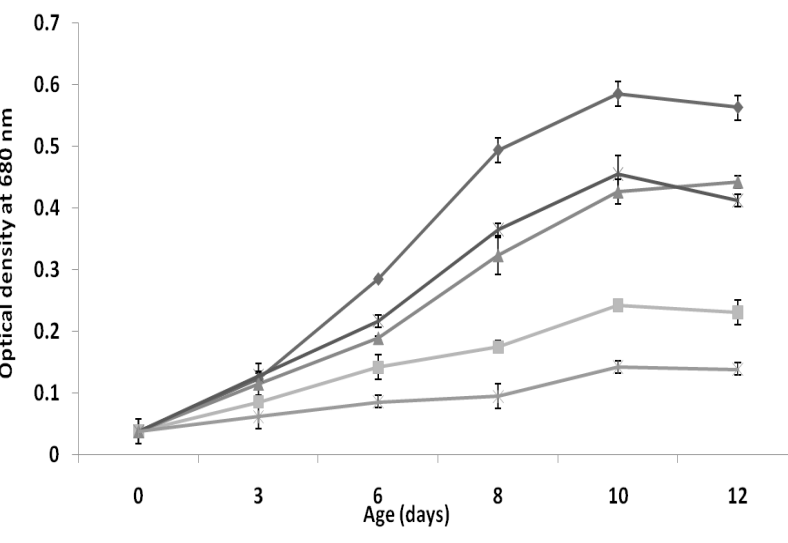

Fig. 4. Growth curves of $N$. oculata on industrial wastewater of A, El- Malyaa Company (EMC); B, Salt and Soda Company (ESC) and F/2 medium as optical density at $680 \mathrm{~nm}$. Each point represents the mean value of three replicates; bars indicate standard deviations.

A

$\begin{array}{ll}\rightarrow \text { Control } & -25 \% \text { ww of EMC } \\ -75 \% \text { ww of EMC } & -100 \% \text { ww of EMC }\end{array}$
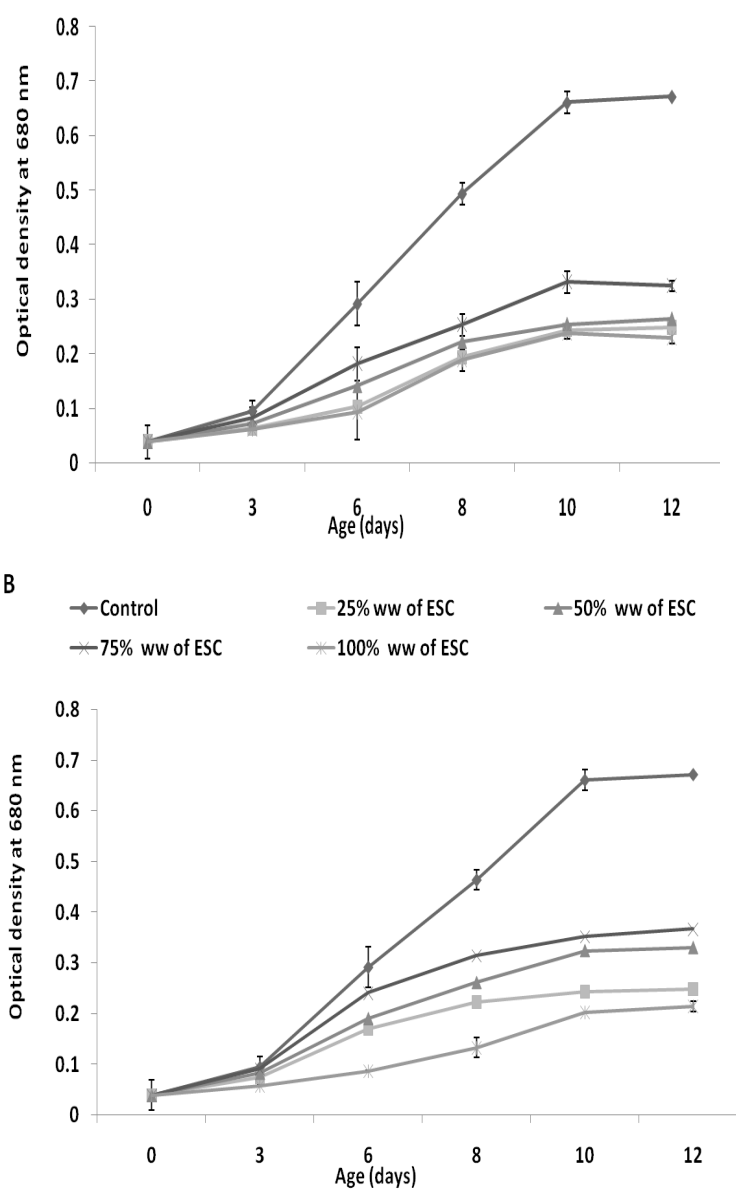

Fig. 5. Growth curves of $T$. chuii on industrial wastewater of A, El- Malyaa Company (EMC); B, Salt and Soda Company (ESC) and F/2 medium as optical density at $680 \mathrm{~nm}$. Each point represents the mean value of three replicates; bars indicate standard deviations. 
TABLE 3. Dry weight and biomass productivity of tested microalgae on industrial wastewater of A, El- Malyaa Company (EMC); B, Salt and Soda Company (ESC) and F/2 medium at the end of exponential phase. Each point represents the mean value of three replicates. Different letters represent significant differences at $\mathbf{P}<0.05$ (Duncans).

\begin{tabular}{|c|c|c|c|c|}
\hline \multirow{2}{*}{$\begin{array}{l}\text { Microalgae } \\
\text { Treatments }\end{array}$} & \multicolumn{2}{|c|}{ N. oculata } & \multicolumn{2}{|c|}{ T. chuii } \\
\hline & $\begin{array}{l}\text { Dry weight } \\
\left.\text { (g.L } \mathrm{L}^{-1}\right)\end{array}$ & $\begin{array}{c}\text { Biomass productivity } \\
\left(\mathrm{g} \cdot \mathrm{L}^{-1} \cdot \mathrm{d}^{-1}\right)\end{array}$ & $\begin{array}{l}\text { Dry weight } \\
\left(\text { g. } \mathrm{L}^{-1}\right)\end{array}$ & $\begin{array}{c}\text { Biomass productivity } \\
\left(\mathrm{g} \cdot \mathrm{L}^{-1} \cdot \mathrm{d}^{-1}\right)\end{array}$ \\
\hline Control & $0.59 \pm 0.01^{\mathrm{A}}$ & $0.058 \pm 0.001^{\mathrm{A}}$ & $0.722 \pm 0.05^{\mathrm{A}}$ & $0.077 \pm 0.003^{\mathrm{A}}$ \\
\hline $25 \% \mathrm{ESC}$ & $0.311 \pm 0.03^{\mathrm{E}}$ & $0.025 \pm 0.001^{\mathrm{G}}$ & $0.352 \pm 0.01^{\mathrm{G}}$ & $0.03 \pm 0.001^{\mathrm{H}}$ \\
\hline $50 \%$ ESC & $0.383 \pm 0.04^{\mathrm{D}}$ & $0.035 \pm 0.002^{\mathrm{D}}$ & $0.411 \pm 0.02^{\mathrm{F}}$ & $0.038 \pm 0.002^{\mathrm{F}}$ \\
\hline $75 \%$ ESC & $0.455 \pm 0.04^{\mathrm{B}}$ & $0.041 \pm 0.001^{\text {в }}$ & $0.514 \pm 0.03^{\mathrm{C}}$ & $0.048 \pm 0.002^{\mathrm{C}}$ \\
\hline $100 \% \mathrm{ESC}$ & $0.235 \pm 0.01^{\mathrm{G}}$ & $0.017 \pm 0.001^{\mathrm{I}}$ & $0.315 \pm 0.03^{\mathrm{H}}$ & $0.028 \pm 0.001^{\mathrm{I}}$ \\
\hline $25 \% \mathrm{EMC}$ & $0.385 \pm 0.02^{\mathrm{D}}$ & $0.032 \pm 0.001^{\mathrm{F}}$ & $0.488 \pm 0.03^{\mathrm{E}}$ & $0.045 \pm 0.003^{\mathrm{E}}$ \\
\hline $50 \%$ EMC & $0.435 \pm 0.02^{\mathrm{C}}$ & $0.033 \pm 0.002^{\mathrm{E}}$ & $0.515 \pm 0.02^{\mathrm{C}}$ & $0.046 \pm 0.001^{\mathrm{D}}$ \\
\hline $75 \%$ EMC & $0.587 \pm 0.04^{\mathrm{A}}$ & $0.043 \pm 0.002^{\mathrm{B}}$ & $0.611 \pm 0.03^{\mathrm{B}}$ & $0.057 \pm 0.002^{\mathrm{B}}$ \\
\hline $100 \% \mathrm{EMC}$ & $0.305 \pm 0.01^{\mathrm{F}}$ & $0.023 \pm 0.001^{\mathrm{H}}$ & $0.335 \pm 0.01^{\mathrm{H}}$ & $0.031 \pm 0.002^{\mathrm{G}}$ \\
\hline F value & $6016 * * *$ & $1516^{* * *}$ & $165367 * * *$ & $2176^{* * *}$ \\
\hline
\end{tabular}

** Significant at $\mathrm{P} \leq 0.05, * * *$ Significant at $\mathrm{P} \leq 0.005$ and (ns) Non-significant at $\mathrm{P} \leq 0.01$ using one way analysis of variance (ANOVA).

A

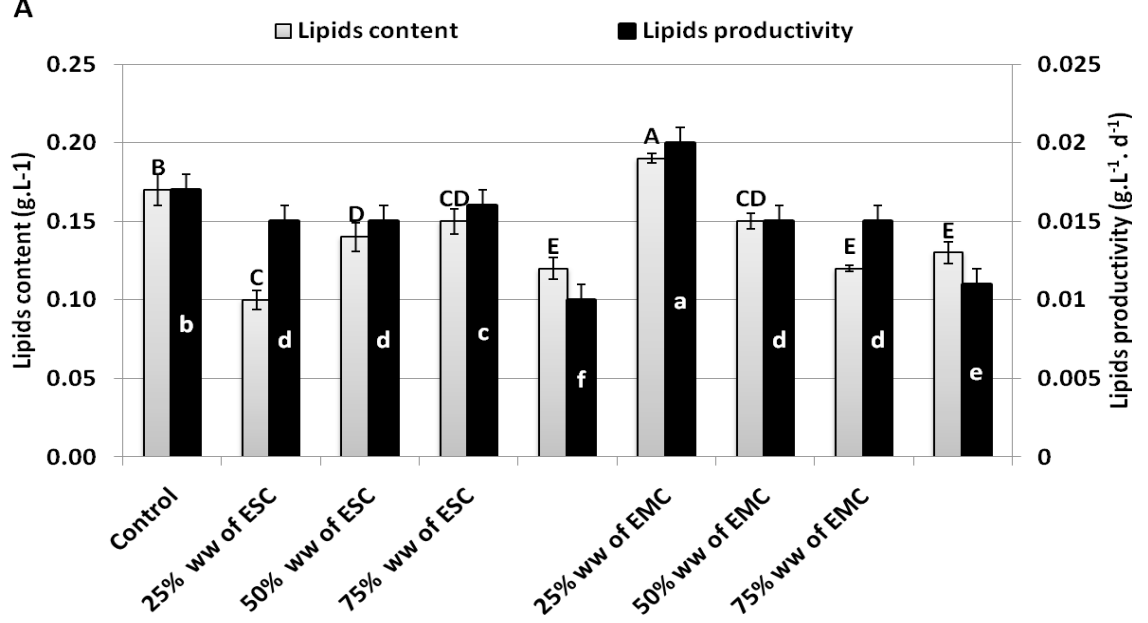

B

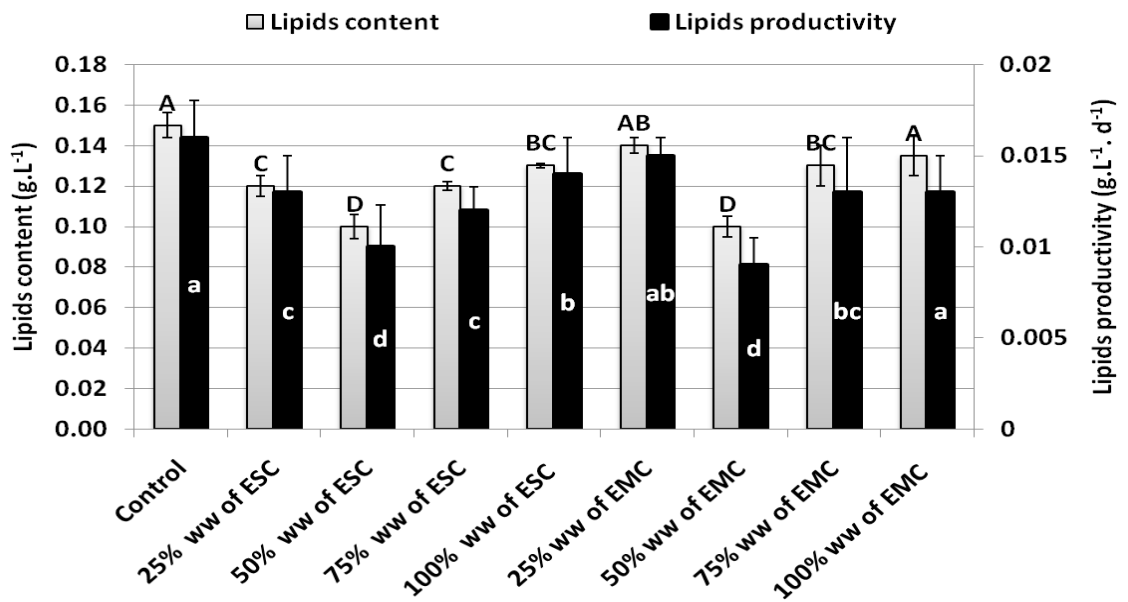

Fig. 6. Total lipids content and lipids productivity of of $\mathrm{A}, N$. oculata and $\mathrm{B}, T$. chuii on industrial wastewater (ESC) or (EMC) and F/2 medium during the end of exponential phase. Each point represents the mean value of three replicates; bars indicate standard deviations. Different letters represent significant differences at $P$ $<0.05$ (Duncans). 


\section{Conclusion}

The possibilities of the economic importance of microalgal biomass in biodiesel production are well known. The results of this study suggest that cultivating microalgae on industrial wastewater combines nutrients removal and algal lipid production for potential use as a biodiesel feedstock. Additionally, using the industrial wastewater, as nutrient media for microalgae cultivation, is suitable and nonexpensive method. Cultivation of tested strains on a mixture of industrial wastewater and synthetic medium increased their total lipids content and its percentage of dry weight than the cultivated species on synthetic medium only.

\section{References}

Abdel-Raouf, N., Al-Homaidan, A.A. and Ibraheem, I.B.M. (2012) Microalgae and wastewater treatment. Saudi Journal of Biological Sciences, 19, 257-275.

Allen, M., Grimshaw, H., Parkinson, A. and Quarmby, C. (1974) "Chemical Analysis of Ecological Materials". Blackwell Scientific Publications. 565pp.

Dash, H., Mangwani, N., Chakraborty, J. and Kumari, S. (2013) Marine bacteria: Potential candidates for enhanced bioremediation. Applied Microbiology and Biotechnology, 97, 561-571.

Davis, G.T., Nirmala, M.,.Natarajan, M. and Polur, H.R. (2016) Cultivation of microalgae in domestic wastewater for biofuel applications. An upstream approach. Journal of Algal Biomass Utilization, 7(1), 62-70.

Dismukes, G.C., Carrieri, D., Bennette, N., Ananyev, G.M. and Posewitz, M.C. (2008) Aquatic phototros: Efficient alternatives to land-based crops for biofuels. Curr. Opin. Biotechnol. 19, 235-240.

Dytham, C. (1999) "Choosing and Using Statistics: A Biologist's Guide". Blackwell Science, London, UK.

Ellis,T.G.(2011)Chemistryofwastewater."Environmental and Ecological Chemistry", Volume II, pp.452.

El-Sheekh, M., El-Shouny, W., Osman, M. and ElGammal, E. (2005) Growth and heavy metals removal efficiency of Nostoc muscorum and Anabaena subcylindrica in sewage and industrial wastewater effluents. Environmental Toxicology and
Pharmacology, 19, 357-365.

Folch, J., Lees, M. and Stanley, G.H.S. (1957) A simple method for the isolation and purification of total lipids from animal tissues. Journal of Biological Chemistry, 226, 497-509.

Gouveia, L. and Oliveira, A.C. (2009) Microalgae as a raw material for biofuels production. Journal of Industrial Microbiology and Biotechnology, 36, 269274.

Guillard, R. and Ryther, J. (1962) Studies of marine planktonic diatoms Cyclotella nana Hustedt and Detonula confervacea Cleve. Can. J. Microbiol. 8, 229-239.

Hemschemeier, A, Melis, A. and Happe, T. (2009) Analytical approachs to photobiological hydrogen production in unicellular green algae. Photosyn. Res. 102, 523-540.

Jackson, A. A., Golden, M.H., Jahoor, P.F. and Landman, J.P. (1980) The isolation of urea nitrogen and ammonia nitrogen from biological samples for mass spectrometry. Analytical Biochemistry, 105(1), 14-17.

Karpagam, R., Raj, K.J., Ashokkumar, B. and Varalakshmi, P. (2015) Characterization and fatty acid profiling in two fresh water microalgae for biodiesel production: Lipid enhancement methods and media optimization using response surface methodology. Bioresource Technology, 188, 177-184.

Karuppaiah, L., Suntharam, R. and Perumal, M. (2015) Bioremediaton of tannery effluent using Lyngbya $\mathrm{Sp}$. with coir pith. International Journal of Science and Research, 4(1), 2736-2743.

Lim, S., Chu, W. and Phang, S. (2010) Use of Chlorella vulgaris for bioremediation of textile wastewater. $J$. Bioresour. Technol. 101, 7314-7322.

Mouchet, P. (1986) Algal reactions to mineral and organic micropollutants, ecological consequences and possibilities for industrial scale application; a review. Water Res. 20, 399-412.

Onalo, J.I., Matias-Peralta, H.M. and Sunar, N.M. (2014) Growth of freshwater microalga, Botryococcus sp. in heavy metal contaminated industrial wastewater. Journal of Science and Technology, 6(2), 29-40. 
Oswald, W.J. (1988) Micro-algae and waste-water treatment. In: "Micro-algal Biotechnology" Borowitzka, M.A., Borowitzka, L.J. (Ed.), p 305328. Cambridge University Press, Oxford.

Oswald, W.J. (2003) My sixty years in applied algology, J. Appl. Phycol. 15, 99-106.

Scott, S.A., Davery. M.P., Dennis, J.S., Horst, I., Howe, C.J. and Lea-Smith, D.J. (2010) Biodiesel from algae: Challenges and prospects. Curr. Opin. Biotechnol. 21, 277-286.

Sousa, L.L., Dominique, S.H., Emerson, A.S. and Louisa, W.P. (2014) Cultivation of Nannochloropsis sp. in brackish groundwater supplemented with municipal wastewater as a nutrient source. Brazilian Archives of Biology and Technology, 57(2), 171-177.

Stephens, E., Ross, I.L., King, Z., Mussgnug, J.H., Kruse, O., Posten, C., Borowitzka, M. and Hankamer, B. (2010) An economic and technical evaluation of microalgal biofuels. Nature Biotechnol. 28, 126-128.

Stover, R., Sommers, L.E. and Silviers, D.J. (1976) Evaluation of metals in wastewater sludge. J. Water Pollut. Control Fed. 48, 2165-2175.

Strickland, J.D. and Parasons, R. (1972) "A Manual of Seawater Analysis". $3^{\text {rd }}$ ed. Bull. Fish. Res. Bd. Canada, Ottawa, Bull. No. 145.
Strickland, J.D. and Parasons, T.R. (1965) "A Manual of Seawater Analysis". $2^{\text {nd }}$ ed. Bull. Fish. Res. Bd. Canada, Ottawa, Bull. No. 125.

Sutherl, D., Howard-Williams, C., Turnbull, M., Broady, P.A. and Craggs. R.J. (2014) Enhancing microalgal photosynthesis and productivity in wastewater treatment High Rate Algal Ponds for biofuel production, Bioresource Technology, 10, 74.

Umamaheswari, J. and Shanthakumar, S. (2016) Efficacy of microalgae for industrial wastewater treatment: A review on operating conditions, treatment efficiency. (2016). Rev. Environ. Sci. Biotechnol. 15, 265-284.

Wang, C., Yu, X., Lv, H. and Yang, J. (2013) Nitrogen and phosphorus removal from municipal wastewater by the green alga Chlorella sp. Journal of Environmental Biology, 34 (2 suppl), 421.

Zhou, W., Li, Y., Min, M., Hu, B., Chen, P. and Ruan, R. (2011) Local bioprospecting for highlipid producing microalgal strains to be grown on concentrated municipal wastewater for biofuel production. BioresourTechnol. 102, 6909-6919.

(Received 26 / 3 /2017; accepted 24 / 2 /2018) 


\section{امكانية زراعة الطحالب الزيتية المحبة للملوحة على مياه الصرف الصناعي

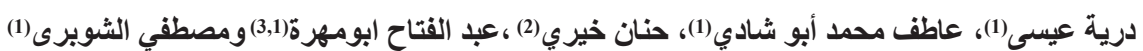

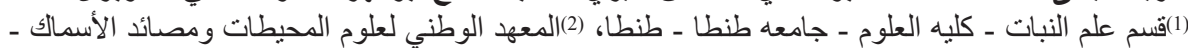 الإسكندرية ـ مصر و (3)مدرسه الطاقة و هندسه الطاقة - جامعه جيانغ سو - 310212 جيانغ سو - الصين.}

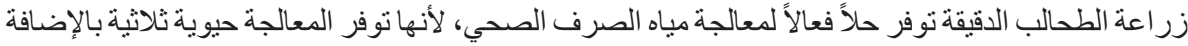

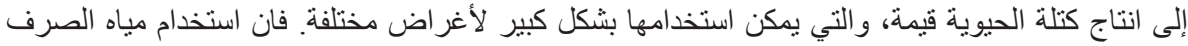

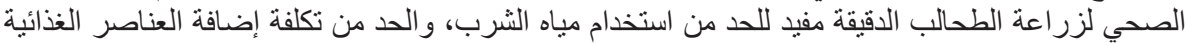
وباضافة إلى تنقية مياه الصرف الطحسي من النيتروجين و الفوسفور .

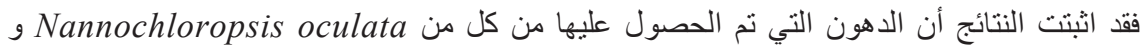
Tetraselmis chuii لشركة المالية (EMC) وشركة الملح و الصودا (ESC) كوسط نمو للطحالب البحرية الزيتية التي تم اختبار ها.

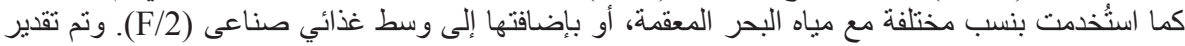

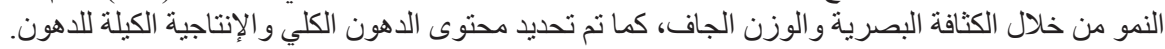

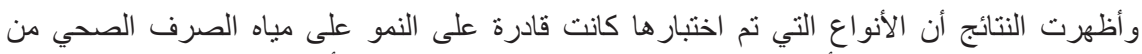

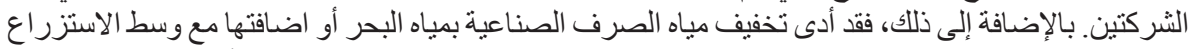

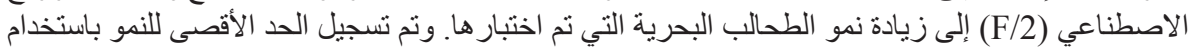

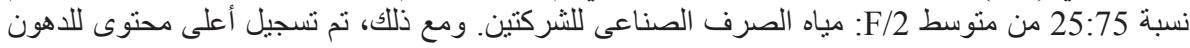

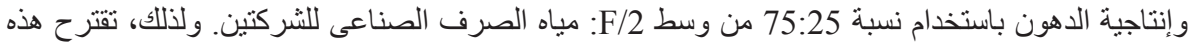

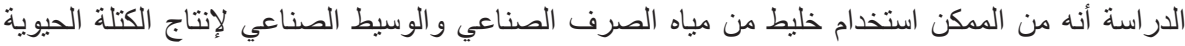
و الدهون من الطحالب الدقيقة لإنتاج الوقود الدئ من الحيوي. 